\title{
Combined influence of bud load and bud position along the cane on vegetative and reproductive parameters of grape cv. Grillo
}

\author{
Rosario Di Lorenzo ${ }^{1}$, and Antonino Pisciotta ${ }^{1, *}$ \\ ${ }^{1}$ University of Palermo, Department of Agricultural, Food and Forest Sciences (SAAF), Viale delle Scienze ED 4 Ing. H, \\ 90133 Palermo, Italy.
}

\begin{abstract}
Cultivar Grillo vines are characterized by problems with flower biology (the fertility of basal buds) and fructification (millerandage). In this study, to manage the variability in bunch weight with winter pruning and to program others canopy management practices (i.e. early defoliation), three different treatments of bud load were set up by leaving the cane with 3,6 or 10 buds. The effects of bud load and cane length were studies regarding bud fertility, shoot leaf area, and the number of flowers and berries, as well as the relationship between leaf area and percentage of fruit set, leaf area/flower and percentage of fruit set, and the number of hens and chicks berries. Shoots in the distal position had higher values of fertility and inflorescences with a greater number of flowers, while no 'apical' effect of the buds emerged. A good relationship was found between fruit set and the number of flowers, leaf area at flowering and yield, and square centimeters/flower and percentage of fruit set. Cane length was found to be a valid tool for managing bunch weight variability; the value of the leaf area/flower can be used to program early defoliation practice carried out to manage berry set .
\end{abstract}

\section{Introduction}

Grapevine (Vitis vinifera L.) is considered one of the most important perennial fruit crops in the world. 'Grillo' is one of the old varieties cultivated in Sicily. It is a medium- to late-ripening cultivar that produces medium to large conical and quite thick clusters with prominent shoulders. The berries are quite large in size (around $3 \mathrm{~g}$ ) and the cultivar is prone to poor fruit setting (millerandage) [1]. Winter pruning is considered the most important practice through which grape yield can be regulated and grape quality improved. The basal 3-4 buds of the Grillo cultivar are less fruitful, so using long fruit canes is important for achieving a remunerative crop. Bud load is the most important factor affecting yield and cluster quality, as well as vine vigour, in Thompson seedless grapevines $[2,3,4,5,6]$, the Tempranillo variety [7], and Crimson seedless grapevines. The objective of this study was to determine the optimum bud load/vine for Grillo grapes and to study the effect of bud load on leaf area, the number of flowers/cluster, and fruit set.

\section{Materials and Methods}

This work was carried out in 2017 in a private vineyard located in western Sicily $\left(37^{\circ} 55^{\prime} 06.16^{\prime}\right.$ ' N, $13^{\circ} 03^{\prime}$ 45.96' E) on 10 year-old Grillo/1103P grapevines. The vines were spaced $1 \mathrm{~m}$ in rows and $2.3 \mathrm{~m}$ between rows in a clay soil under drip irrigation and trained to a bilateral Guyot with vertically shoot positioned. At winter pruning time, 72 vines of similar vigour were selected and pruned to different bud load levels with variable length of the canes. The vines received the usual and recommended agriculture practices.

The experimental treatments applied were as follows:

$\mathrm{T} 1-2$ spur X $3 \mathrm{bud} / \mathrm{spur}=6$ buds

$\mathrm{T} 2-2$ canes $\mathrm{X} 6 \mathrm{bud} / \mathrm{cane}=12$ buds

$\mathrm{T} 3$ - 2 canes $\mathrm{X} 9 \mathrm{bud} / \mathrm{cane}=18$ buds

In each treatment, an additional renewal two-node spur was retained. Each treatment included three replicates of 14 vines within a randomised complete block design. The following parameters were investigated for each experimental vine.

Bud behaviour: During the spring, the number of burst buds, blind buds and fruitful buds were counted, and the percentages of bud burst, blind bud, fertility and fruitfulness were calculated according to [8]. Also, the number of clusters/vine was counted.

Shoot: The total number of shoots/vine was counted and the leaf area/shoot was measured on 15 shoots/replicate at flowering and at harvest.

Cluster: The number of flowers/cluster position (primary and secondary) were manually counted at flowering. The average yield/vine was determined as the average of number of clusters/vine and the average weight of clusters/vine in kilograms at harvesting. Representative

\footnotetext{
Corresponding author: antonino.pisciotta@unipa.it
} 
samples/replicate were harvested and taken to the laboratory to determine the average cluster weight $(\mathrm{g})$; number of berries/cluster; number of chicken berries/cluster, and the weight of normal berries and chicken berries (g).

Calculated parameters: Setting (number of berries/bunch divided the number of flowers/cluster $x$ 100), leaf area/vine, and leaf area/flower were calculated. Furthermore, correlations were made between the number of flowers and the leaf area/vine, setting and the number of flowers/vine, as well as vine leaf area at flowering and yield at harvest.

The data were tabulated and statistically analysed using the ANOVA at the 5\% level of significance to compare the differences between various treatments, using the Tukey post-hoc test. A regression analysis was also performed.

\section{Results and discussion}

Based on Table 1, it was clear that the number of blind buds, along portions 1-3, increased significantly by increasing the bud load/vine during the season. The highest value was $53 \%$ for 18 buds/vine. However, a higher bud load/vine led to a lower percentage of blind buds in portions 4-6 and 7-9 with 12 and 18 buds/vine.

Table 1. Effect of bud load and node position on bud behaviour and shoot fertility in cv. Grillo. Different letters within a column indicate significant differences as calculated by the Tukey test $(\mathrm{p} \leq 0.01) .{ }^{\mathrm{y}}=$ or lowercase letters are differences within the treatment; ${ }^{\mathrm{z}}=$ or uppercase letters, differences among treatments. n.s. $=$ not significant.

\begin{tabular}{|c|c|c|c|c|c|c|c|}
\hline \multirow[t]{2}{*}{$\begin{array}{l}\text { Buds/ } \\
\text { cane }\end{array}$} & \multirow[t]{2}{*}{ Node } & \multirow[t]{2}{*}{$\begin{array}{l}\text { Blind } \\
\text { buds } \\
(\%)\end{array}$} & \multicolumn{3}{|c|}{$\begin{array}{c}\text { Shoot/fertility } \\
\text { level }(\%)\end{array}$} & \multirow[t]{2}{*}{$\begin{array}{l}\text { Shoot } \\
\text { Fertility } \\
\text { (n) }\end{array}$} & \multirow{2}{*}{$\begin{array}{l}\text { Fertile } \\
\text { shoot } \\
\text { fertility } \\
(\mathrm{n})\end{array}$} \\
\hline & & & 0 & 1 & 2 & & \\
\hline 6 & $1-3$ & 21 & 15 & 21 & 43 & $1.33 B^{z}$ & 1.65 \\
\hline \multirow{3}{*}{12} & $1-3$ & 42 & 13 & 18 & 27 & $1.23 \mathrm{a}^{\mathrm{y}}$ & $1.59 \mathrm{a}$ \\
\hline & $4-6$ & 8 & 12 & 22 & 58 & $1.50 \mathrm{~b}$ & $1.72 \mathrm{~b}$ \\
\hline & $A V G$ & 25 & 13 & 20 & 42 & $1.36 \mathrm{~B}$ & 1.66 \\
\hline \multirow{4}{*}{18} & $1-3$ & 53 & 21 & 10 & 16 & $0.87 \mathrm{a}$ & $1.59 \mathrm{a}$ \\
\hline & 4-6 & 4 & 21 & 18 & 57 & $1.35 \mathrm{~b}$ & $1.76 \mathrm{~b}$ \\
\hline & $7-9$ & 11 & 18 & 15 & 56 & $1.44 \mathrm{~b}$ & $1.81 \mathrm{~b}$ \\
\hline & $A V G$ & 23 & 20 & 15 & 42 & $1.22 \mathrm{~A}$ & $1.72 n . s$. \\
\hline
\end{tabular}

No differences were found in terms of the percentage of shoots with two bunches (on average $42 \%$ for all treatments). Moreover, with regard to the percentage of blind buds, it was clear that the percentage of shoots with a single bunch or no bunches was affected by bud load/vine. In this respect, the percentage of shoots with one bunch decreased from 6 to 18 buds/vine $(21 \%, 20 \%$ and $15 \%$, respectively), while the percentage of unfertile shoots increased from $6 / 12$ to 18 buds/vine $(15 \%, 13 \%$ and $20 \%$, respectively). Vines pruned with 18 buds showed the lowest shoot fertility (1.22), while no differences were shown in terms of fertility in fertile shoots.

Table 2 clearly indicates that the number of flowers/cluster increased significantly as bud load increased in shoots with one or two clusters. In addition, the flower number/cluster increased along the cane from node 1-3 to 7-9 in shoots with one or two clusters. According to these results, it is obvious that the treatment with 18 buds/vine provided the highest number of flowers/vine at 12,803, 12 and 6 buds/vine provided 5,871 and 1,927 flowers/vine, respectively.

Table 2. Effect of bud load and node position on the number of flowers in primary and secondary clusters and flowers/vine in cv. Grillo. Different letters within a column indicate significant differences calculated by the Tukey test $(\mathrm{p} \leq 0.01) .{ }^{\mathrm{y}}=$ or lowercase letters are differences within the treatment; ${ }^{\mathrm{z}}=$ or uppercase letters, differences among treatments. n.s. $=$ not significant.

\begin{tabular}{|c|c|c|c|c|c|}
\hline Buds/ & Node & \multicolumn{3}{|c|}{ Flowers/fertility level (n) } & \multirow{2}{*}{$\begin{array}{c}\text { Flowers/vine } \\
\text { (n) }\end{array}$} \\
\hline & & $\mathbf{0}$ & 1 & 2 & \\
\hline 6 & $1-3$ & - & $300 \mathrm{~A}^{\mathrm{z}}$ & $596 \mathrm{~A}$ & $1927 \mathrm{~A}$ \\
\hline \multirow{3}{*}{12} & $1-3$ & - & $233 \mathrm{a}^{\mathrm{y}}$ & $701 \mathrm{a}$ & \multirow{3}{*}{$5871 \mathrm{~B}$} \\
\hline & $4-6$ & - & $464 \mathrm{~b}$ & $1117 \mathrm{~b}$ & \\
\hline & $A V G$ & - & $348 \mathrm{~A}$ & $909 B$ & \\
\hline \multirow{4}{*}{18} & $1-3$ & - & $339 \mathrm{a}$ & $983 \mathrm{a}$ & \multirow{4}{*}{$12803 \mathrm{C}$} \\
\hline & $4-6$ & - & $618 \mathrm{~b}$ & $1227 \mathrm{~b}$ & \\
\hline & $7-9$ & - & $711 \mathrm{~b}$ & $1377 \mathrm{~b}$ & \\
\hline & $A V G$ & - & $556 B$ & $1196 \mathrm{~B}$ & \\
\hline
\end{tabular}

Physiologically, leaf area has been found to largely influence the photosynthetic efficiency and transport of most photosynthates required for the growth and developmental activity of reproductive structures. Thus, obtaining an estimation of leaf area is essential to the growth process and is often important in vegetative and physiology by predisposing to growth and development, which strongly influence crop productivity [9].

The growth parameter leaf area was assessed at flowering and at harvest during the season. A positive relationship was found between the number of flowers and vine leaf area $\left(\mathrm{R}^{2}=0.67\right)$ in cv. Grillo, indicating the relative importance of the entire vine over single shoot vigour $\left(\mathrm{R}^{2}=0.1\right)$ (Fig. 1$)$.

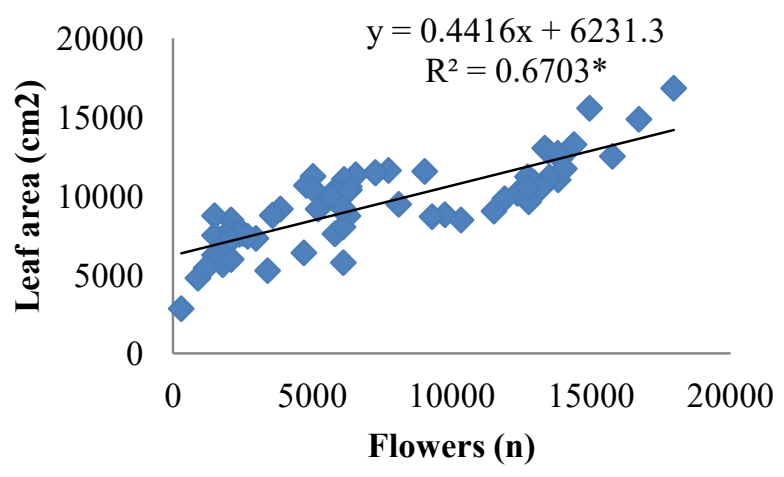

Fig. 1. Regression analysis between flowers and leaf area/vine of in. Grillo 
The number of flowers plays an important role in determining the percentage of setting. The literature reports an average of $20 \%$ for setting in grapes, but no data have been described in terms of the number of flowers. In the Grillo variety, a correlation was found between setting percentage and the number of flowers $\left(\mathrm{R}^{2}=0.90\right)$. Thus, $20 \%$ setting was found with 10,000 to 20,000 flowers/vine, while this value was more than $30 \%$ with fewer than 4000 flowers/vine (Fig. 2).

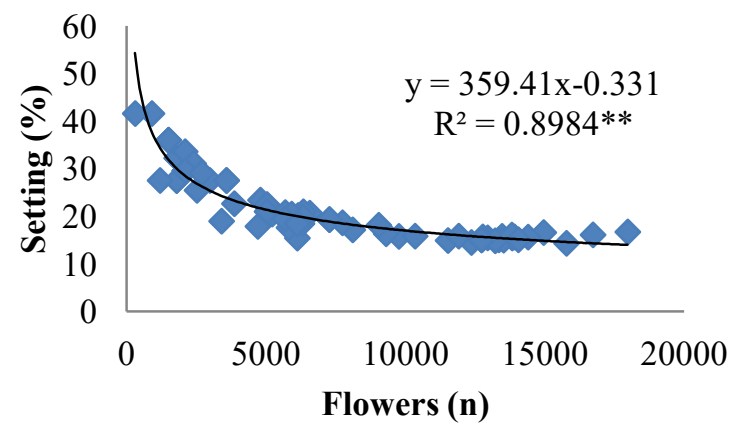

Fig. 2. Regression analysis between flowers/vine and the percentage of setting in cv. Grillo

The bunch weight and yield/vine data presented in Table 3 clearly indicate that productive parameters were increased significantly as bud load increased. It was obvious that the treatment with 18 buds/vine gave the highest yield/vine recorded (4333.3 g) in the season while the $6 \mathrm{bud} / \mathrm{vine}$ treatment gave the lowest value (1303 g). According to [10], pruning to the 4-bud level gave a significantly higher yield than 6-bud pruning. [11] tested different pruning levels and found that, as the severity of pruning increased, the yield decreased. [12] observed in cv. Delight grapes that the average yield/vine increased with decreased intensity of pruning. [13] concluded that in cv. Festival Seedless, the yield/vine increased linearly (3.93 to $11.87 \mathrm{~kg} / \mathrm{vine}$ ) as pruning intensity decreased from 12 to 4 canes with 14 buds/cane. [14] revealed that in cv. Concord, yield increased from 4.0 to $23.0 \mathrm{~kg} / \mathrm{vine}$ as bud load increased from 20 to 160 buds/vine. [15] reported that there was an increase in yield in direct proportion to a higher node number. [16] revealed that yield, cluster/vine, and crop load increased with increasing shoot density, but cluster weight, berries/cluster, and berry weight were reduced significantly.

Table 3. Effect of bud load and node position on bunch mass and yield/vine in cv. Grillo. Different letters within a column indicate significant differences as calculated by the Tukey test $(p \leq 0.01){ }^{y}=$ or lowercase letters are differences inside the treatment; ${ }^{\mathrm{z}}=$ or uppercase letters, differences among treatments. n.s. $=$ not significant.

\begin{tabular}{|c|c|c|c|c|}
\hline $\begin{array}{c}\text { Buds/ } \\
\text { cane }\end{array}$ & Node & \multicolumn{2}{|c|}{ Bunch (g) } & \multirow{2}{*}{ Yield (g) } \\
\hline & & $\mathbf{1}$ & $\mathbf{2}$ & \\
\hline \multirow{2}{*}{$\mathbf{6}$} & $1-3$ & $308.3 \mathbf{A}^{\mathbf{z}}$ & 191 & $1303.0 \mathrm{~A}$ \\
\hline \multirow{3}{*}{$\mathbf{1 2}$} & $1-3$ & 242.7 & $155.5 \mathrm{a}$ & \multirow{2}{*}{$2727.6 \mathrm{~B}$} \\
\cline { 2 - 4 } & $4-6$ & 286.8 n.s. & $210.9 \mathrm{~b}$ & \\
\cline { 2 - 4 } & $\boldsymbol{A V G}$ & $\mathbf{2 6 7} \boldsymbol{B}$ & $\mathbf{1 8 3 . 2}$ & \\
\hline
\end{tabular}

\begin{tabular}{|c|c|c|c|c|}
\hline \multirow{4}{*}{18} & $1-3$ & $181.4 \mathrm{a}^{\mathrm{y}}$ & $207.8 \mathrm{~b}$ & \multirow{4}{*}{$4333.3 \mathrm{C}$} \\
\hline & $4-6$ & $176.6 \mathrm{a}$ & $155.2 \mathrm{a}$ & \\
\hline & $7-9$ & $264.4 \mathrm{~b}$ & $213.6 \mathrm{~b}$ & \\
\hline & $A V G$ & $207.5 C$ & 192.9 n.s. & \\
\hline
\end{tabular}

[17] observed that in cv. Thompson Seedless, the highest yield/vine $(15.96 \mathrm{~kg})$ was recorded with a cane density of $35 /$ vine. However, a low yield/vine $(8.43 \mathrm{~kg})$ was registered at a cane density of $30 /$ vine. According to several authors, this behaviour can be different according to the variety; in fact, [18] observed that the 4 buds/cane level led to the maximum yield/vine in $c v$. 'Pinot Noir', 'Ugni Blanc' and 'Sauvignon Blanc', while the 6 buds/cane level provided the maximum yield/vine in 'Syrah' and 'Grenache'. This increase in vine yield may be attributed in better flower set, improved pollen viability, germination and fertilisation, better fruit set, reduced fruit drop, increased berry size, and a reduction in shot berries [19], or to an increase in both the number of clusters/vine and their weight. These results agree with those obtained by [20 \& 5] on Thompson seedless grapevines. In our case, differences in yield were attributed to an increase in the number of fertile shoots (Table 1) and an obvious increase in the number of bunches/vine [13, 21, 22]. A better explanation can be found by looking at bunch weight behaviour (Table 3), which was negatively correlated with bud load [23]. [24] in cv. 'Himrod' found the maximum value of bunch weight with the lowest bud/vine treatments. [12] observed a reduction in bunch weight due to pruning levels in 'Delight' grapes. It was recorded that 2 buds/spur led to a higher bunch weight as compared to 6 buds/spur.

In our trial, in cv. Grillo, the maximum bunch weight $(308.3 \mathrm{~g})$ was observed in the main cluster, at the 6 buds/vine level, obviously in nodes 1-3 of the cane; no differences were found between node positions with 12 buds/vine (267 g), while with 18 buds/vine, the biggest bunch was observed in node positions 7-9 (264.4 g); this was on par with nodes 1-3 and 4-6 (181.4 g and $176.6 \mathrm{~g}$ respectively). Secondary bunches registered higher values in nodes 4-6 for 12 buds/vine (155.5 g and 210.9 $\mathrm{g}$ in nodes 1-3 and 4-6, respectively) and in nodes 1-3 and 7-9 for $18 \mathrm{buds} /$ vine $(207.8 \mathrm{~g}, 155.2 \mathrm{~g}$, and $213.6 \mathrm{~g}$ in nodes 1-3, 4-6 and 7-9, respectively) (Table 3). These results are in contrast in what was observed in cv. Merlot when the vines were pruned at 2 to 9 buds/cane; the maximum yield was recorded in the fifth bud position followed by sixth bud position [17].

Viticulture seeks to manipulate the balance between vegetative growth and fruiting in grapevines. This is done for a variety of reasons, such as ensuring that crops ripen adequately and guaranteeing vineyard profitability. Another fundamental viticulture target is to predict the yield as early as possible. To correct prediction of yield should be informed by vineyard variability. At flowering and fruitset, the number of berries/bunch typically explains around $20-30 \%$ of the total annual variation in yield. 


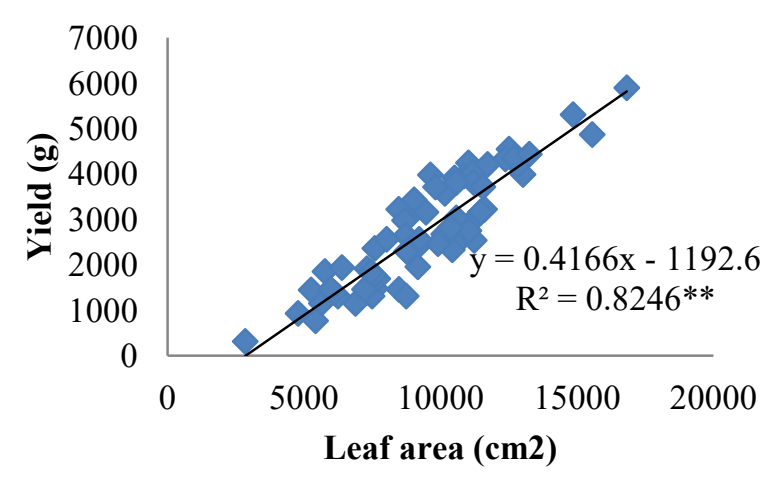

Fig. 3. Regression between leaf area and yield/vine in cv. Grillo

Considering that the weather conditions around this stage of development can have a major influence on the success of these flowering and fertilisation processes, during our trial, a positive relationship $\left(\mathrm{R}^{2}=0.82\right)$ was found between vine leaf area at flowering and yield at harvest (Fig. 3). For instance, in the spring when it is possible to estimate the number of inflorescences/vine, it is not possible to know how large bunches will be at harvest. This is a function of how many flowers are on the inflorescences, how many of these flowers set fruit, and how the berries grow. However, there are key times during grapevine phenology when yield potential is set and a prediction of yield can be made from measurements of crop components at these important phenological stages. A forecast for any contiguous patch of vines at this time is based on estimating the number of flower clusters (inflorescences) in the patch, and predicting average bunch weight at harvest. These forecasts are not as accurate, as forecasts can be made after fruit set when a better estimate of bunch size is available [25].

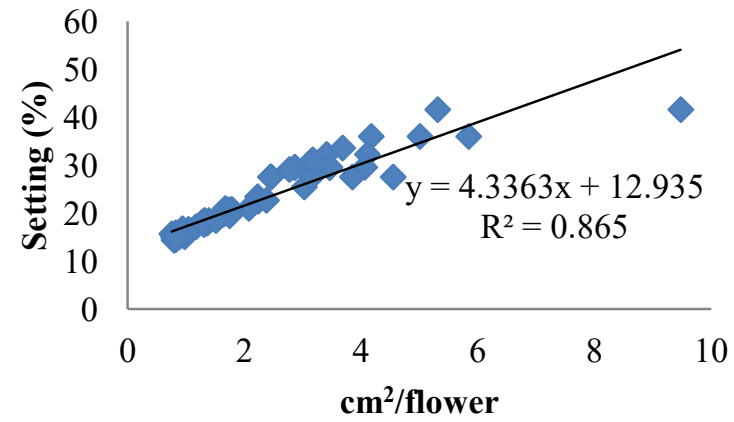

Fig. 4. Regression between leaf area/flower and percentage of setting in cv. Grillo

Nevertheless, this can still be extremely useful as a positive relationship has been shown between reproductive and vegetative growth $\left(\mathrm{R}^{2}=0.86\right)$ with a linear correlation between leaf area/flower and the percentage of setting, meaning that as the leaf area available/single flower increases, berry setting increases correspondingly (Fig. 4). This desirable relationship will therefore ensure that sufficient vegetative growth occurs to sustain the increased amount of fruit and, as a result, improve grapevine sustainability. In cv. Grillo, increasing the number of buds/vine from 6 to 18 (from $100 \%$ to $200 \%$ ) proportionally increased the leaf area $(141 \%$ and $225 \%$ with 12 and 18 buds/vine, respectively) and yield/vine (101\% and $232.5 \%$ with 12 and 18 buds/vine, respectively), while different growth was observed in the number of flowers/vine (which increased by $204.6 \%$ and $564.3 \%$ with 12 and 18 buds/vine, respectively) (Table 4).

Table 4. Percentage differences among treatments in terms of buds number, flowers, leaf area and yield/vine in cv. Grillo.

\begin{tabular}{|c|c|c|c|c|}
\hline & $\begin{array}{c}\text { Buds } \\
(\mathrm{n})\end{array}$ & $\begin{array}{c}\text { Flowers } \\
(\mathrm{n})\end{array}$ & $\begin{array}{c}\text { Leaf area } \\
\left(\mathrm{cm}^{2}\right)\end{array}$ & $\begin{array}{c}\text { Yield } \\
(\mathrm{g})\end{array}$ \\
\hline & & & & \\
\hline$\%$ & $\mathbf{6}$ & 1927.2 & 15339 & 1303 \\
\hline & $\mathbf{1 2}$ & 5871.1 & 37013 & 2627 \\
\hline$\%$ & +100 & +204.6 & +141 & +101.6 \\
\hline & $\mathbf{1 8}$ & 12802.7 & 49914 & 4333 \\
\hline$\%$ & +200 & 564.3 & +225 & +232.5 \\
\hline
\end{tabular}

Thanks to 'Tenute Rapitalà' and their technicians for assistance and technical advice.

\section{References}

1. M.G. Barbagallo, G. Domina, F. Scafidi, A. Pisciotta. Acta Hort. 1229, 195-199 (2018)

2. J.R Morris, D.L. Cawthon. J. Am. Soc. Hort. Sci. 105, 307-310 (1980)

3. F. Fawzi, A.Z. Bondok, G.F. Ghobrial. Annals Agric., Sci., Ain Shams Univ., Cairo 29(1), 465-474 (1984)

4. I.A. Marwad, N. A Rizk, A. H Ibrahim. Egypt. J. Appl. Sci., 8 (12), 47-60(1993)

5. A.H Omar, A. Abdel-Kawi. J. Agric Sci. Mansoura Univ. 25 (9), 5769-5777 (2000).

6. J.A. Rubio, M. V. Albuquerque. J.L Peixy, J. Yuste. Vida Rural, 149, 62-66 (2002)

7. El- El. T. El- Baz, A.M Mansour, El- Dengway, F. El., B.N. Samra. Egypt. J. Hort. 29 (1), 39-60 (2002)

8. Bessis, R. Sur différences mode d'expression quantile de la fertile chez la vigne 828-882 (1960)

9. A. Raj Kumar, S. Parthiban, A. Subbiah, V. Sangeetha. Int. J. Curr. Microbiol. App. Sci. 6 (3), 1814-1826 (2017)

10. K.L. Chadha, H. Kumar. Indian J. Hort., 27, 123-127 (1970)

11. M.E. Byrne, G.S. Howell. Am. J. Enol. Vitic., 29(3), 192-198 (1978)

12. M.S Joon, I.S. Singh. Har. J. Hort. Sci., 12(12), 44-47 (1983) 
13. J.H. Avenant. Deciduous Fruit Grower, 48(5), 7-13 (1998)

14. D.P. Miller, G.S. Howell. Am. J. Enol. Vitic. 49(2), 183-190 (1998)

15. D.I. Jackson, G.F. Steans, P.C. Hemmings. Am. J. Enol. Vitic., 35(3), 161-163 (1984)

16. A.G. Reynolds, C.G. Edwars, D.A. Wordle, D.R. Webster, M. Dever. J. Am. Soc. Hort. Sci., 119, 874-880 (1994)

17. R.A. Chougule. M.Sc., Thesis submitted to MPKV, Rahuri (2004)

18. S.U. Chalak. M.Sc., Thesis submitted to MPKV, Rahuri (2008)

19. P.C. Prabu, P. Singaram. Madras Agric. J. 88, 45-49 (2001)

20. M.A. Ali, M.M. El-Mogy, I. Rizk. Agric. Sci. Mansoura Univ. 25 (3), 1707-1717 (2000)

21. S. Savic, N. Petranovic. Acta. Hort., 652, $217-$ 221 (2004)

22. V.S. Kohale, S.S. Kulkarni, S.A. Ranpise, B.V. Garad. Bioinfolet, 10 (1b), 300 - 302 (2013)

23. C. Popescu. Sci. Hort., 56: 151-154 (2012)

24. 24 Kumar, H. and Tomer, N.S. Har. Hort. Sci., 7 (1-2), 18-20 (1978)

25. P. Clingeleffer. Final Report for Project CSH 96/1: National Approach. 148 (2001) 